\title{
MENGENAL FAKTOR - FAKTOR PSIKOLOGIS YANG MEMBENTUK PERILAKU PEMUSTAKA
}

\author{
Radiya Wira Buwana \\ IAIN Kudus \\ Email: radiyawira@gmail.com
}

\begin{abstract}
Service activities in a library certainly involve interaction between librarians and library users. Users who have different social, economic, and even educational backgrounds result in the formation of a diversity of behavior from users in utilizing library services. Librarian as a representation of the library institution is required to always provide excellent service to visitors without missing anything. A good librarian must have the ability to take a psychological approach with users in order to adapt to a variety of user behaviors. The ability of this psychological approach, of course, must begin with the ability of a librarian to be able to recognize what psychological factors can shape user behavior. Therefore, through this paper the writer introduces the psychological factors that shape the behavior of the users, namely intelligence, perception, personality, attitudes and motivation using a descriptive research approach through library research.
\end{abstract}

Keywords: Library Users, Library Psychology, Librarian

\begin{abstract}
Abstrak : Kegiatan pelayanan di dalam sebuah perpustakaan tentunya melibatkan interaksi antara pustakawan dengan pemustaka. Pemustaka yang memiliki latar belakang sosial, ekonomi, bahkan pendidikan yang berbeda mengakibatkan terbentuknya keanekaragaman perilaku dari pemustaka dalam memanfaatkan jasa perpustakaan. Pustakawan sebagai representasi dari lembaga perpustakaan dituntut untuk selalu memberikan pelayanan yang prima kepada pemustaka tanpa kurang suatu apapun. Seorang pustakawan yang baik harus mampu memiliki kemampuan untuk melakukan pendekatan psikologis dengan pemustaka agar dapat beradaptasi dengan perilaku pemustaka yang beraneka ragam. Kemampuan pendekatan psikologis tersebut tentu harus diawali dengan kemampuan seorang pustakawan untuk dapat mengenal faktor-faktor psikologis apa saja yang dapat membentuk perilaku pemustaka. Oleh karena itu, melalui tulisan ini penulis mengenalkan faktor-faktor psikologis yang membentuk perilaku pemustaka yaitu intelegensi, persepsi, kepribadian, sikap dan motivasi dengan menggunakan pendekatan penelitian deskriptif melalui library research.
\end{abstract}

Kata Kunci : Pemustaka, Psikologi Perpustakaan, Pustakawan 


\section{Radiya Wira Buwana, Mengenal Faktor - Faktor Psikologis Yang ...}

\section{PENDAHULUAN}

Perpustakaan dan pemustaka dapat diibaratkan seperti dua mata rantai yang saling berhubungan dan berinteraksi. Sebagai pusat informasi, perpustakaan berfungsi menyediakan sumber informasi atau bahan pustaka yang bisa dimanfaatkan oleh pemustaka dalam kegiatan literasi Informasi mereka. Di sisi yang lain, pemustaka berperan agar sumber informasi yang telah disediakan oleh perpustakaan dapat bermanfaat secara maksimal demi kepentingan masyarakat (pemustaka) secara tepat sasaran dan tepat guna. Hubungan interaksi timbal balik antara perpustakaan dan penggunanya (masyarakat) merupakan salah satu bentuk pengejawantahan dari salah satu tugas dan fungsi perpustakaan dimana perpustakaan berperan membentuk masyarakat yang mempunyai budaya membaca dan belajar sepanjang hayat dengan menjadikan perpustakaan sebagai sumber informasi, ilmu pengetahuan, teknologi, kesenian, dan kebudayaan. ${ }^{1}$

Sudah menjadi sebuah keniscayaan, bahwa setiap pemustaka selalu memiliki harapan untuk mendapatkan pelayanan terbaik dari perpustakaan. Dari berbagai latar belakang, motivasi, dan tujuan yang dimiliki oleh pemustaka dalam memanfaatkan jasa perpustakaan, pemustaka pasti memiliki harapan dan ekspetasi yang sangat tinggi untuk mendapatkan sebuah bentuk pelayanan prima oleh perpustakaan.

Sutarno dalam Rahayu mengemukakan bahwa secara umum pemustaka selalu mengharapkan terciptanya sebuah layanan perpustakaan berkualitas, adapun layanan yang berkualitas tersebut adalah bentuk layanan perpustakaan yang dapat memenuhi keinginan mereka dalam hal seperti berikut ini: ${ }^{2}$

1. Penyediaan informasi yang sesuai dengan keinginan pemustaka.

2. Waktu yang tepat, leluasa, memadai dan tidak terlalu mengikat.

3. Kebebasan, tata cara, dan akses informasi, tidak kaku dengan pengawasan longgar, tetapi tertib, kondusif dan simpatik.

4. Suasana yang menyenangkan, aman tenang dan tenteram

\footnotetext{
${ }^{1}$ Iskandar Iskandar, Manajemen Dan Budaya Perpustakaan (Bandung: Refika Aditama, 2016), 136.

${ }^{2}$ Lisda Rahayu and dkk, Layanan Perpustakaan (Jakarta: Universitas Terbuka, 2019).
} 


\section{Pustakaloka: Zurnal Kajian 2nformasi dan Perpustakaan}

Volume 12 No. 2, Desember 2020

5. Sikap dan perilaku petugas yang penuh perhatia, ramah, bersifat membimbing dan menguasai masalah.

6. Tata tertib yang perpustakaan yang sederhana.

7. Adanya fasilitas dan kemudahan dalam menggunakan fasilitas dan sumber informasi perpustakaan.

8. Memberikan kesan yang baik, menyenangkan dan memuaskan sehingga menimbulkan keinginan pemustaka untuk kembali lagi.

9. Berorientasi kepada kebutuhan pemustaka.

Pelayanan yang prima oleh perpustakaan tidak akan terwujud dengan baik jika pihak pengelola perpustakaan (pustakawan) tidak mampu mengenali serta mempelajari karakter dan perilaku dari pemustaka. Tidak akan mungkin seorang pustakawan mampu memberikan pelayanan yang prima kepada pemustaka jika tidak lebih dahulu mencoba mengenali dengan baik pemustaka yang akan dilayani. Prastowo mengemukakan bahwa mengenal dengan lebih baik adalah memahami dengan benar karakterisitik pemakai Perpustakaan, baik dalam hal tingkatan berpikir, perkembangan emosi, perkembangan sosial, perkembangan moral, maupun kebutuhan perkembangan fisiknya. ${ }^{3}$

Dalam kegiatan pelayanan sehari-hari di perpustakaan, seringkali pustakawan menemukan berbagai karakter dan perilaku pemustaka yang beraneka ragam. Beberapa contoh perilaku pemustaka tersebut, misalnya pemustaka yang memiliki banyak keinginan untuk dipenuhi, pemustaka yang mudah tersinggung jika kebutuhannya tidak dapat terpenuhi, pemustaka yang berbuat gaduh di dalam perpustakaan sehingga mengganggu pemustaka lainnya, atau bahkan bertemu dengan pemustaka yang berperilaku vandalism seperti merusak buku koleksi atau merusak fasilitas sarana prasana di dalam perpustakaan.

Dengan mengedapankan prinsip pelayanan yang prima, seorang pustakawan harus mampu menguraikan apa yang harus dilakukan dan apa yang tidak harus dilakukan dalam menghadapi aneka perilaku pemustaka. Seorang pustakawan secara aktif harus mampu menjadikan dirinya sebagai mitra diskusi yang menyenangkan, ramah dan informatif bagi pemustaka. Sudah tidak

\footnotetext{
${ }^{3}$ Andi Prastowo, Manajemen Perpustakaan Sekolah Profesional (Yogyakarta: Diva Press, 2013).
} 
Radiya Wira Buwana, Mengenal Faktor - Faktor Psikologis Yang ...

jamannya lagi ditemui seorang pustakawan yang melakukan tindakan persuasif jika menemui pengguna Perpustakaan yang berperilaku tidak semestinya atau tidak sesuai aturan yang berlaku di perpustakaan. Seorang pustakawan yang baik, harus mampu melakukan pendekatan secara psikologis dengan pemustaka. Pustakawan harus mampu melihat jauh lebih ke dalam sisi psikologis seorang pemustaka. Melalui kemampuan tersebut, pustakawan diharapkan mampu untuk mencoba lebih mengenal apa, siapa, dan bagaimana pemustaka yang sedang dilayani sehingga dapat memutuskan sikap apa yang nantinya akan diambil. Yusuf dalam Prastowo ${ }^{4}$ menyatakan bahwa setiap pemustaka pada dasarnya mempunyai watak, kebiasaan, kemampuan, kecerdasan, dan minat yang berbeda satu sama lain, baik dilihat dari segi psikologi umum, sosial, maupun dari segi lainnya.

Berdasarkan permasalahan diatas, penulis hendak mengkaji tentang faktor-faktor psikologis yang mampu membentuk perilaku pemustaka. Diharapkan dengan memahami faktor-faktor psikologis tersebut dapat menunjang kemampuan pustakawan dalam memberikan pelayanan yang prima kepada pemustaka.

\section{METODE PENELITIAN}

Tulisan ini menggunakan pendekatan penelitian deskriptif. Arikunto dalam Prastowo ${ }^{5}$ menuliskan bahwa penelitian deskriptif tidak dimaksudkan untuk menguji hipotesis tertentu, tetapi hanya menggambarkan apa adanya tentang sesuatu variable, gejala, dan keadaan. Sementara itu pengumpulan data dalam tulisan ini dilakukan dengan cara library research, yaitu metode pengumpulan melalui buku dan artikel jurnal yang menurut penulis dapat mendukung pembahasan dalam tulisan ini.

\footnotetext{
${ }^{4}$ Prastowo.

${ }^{5}$ Andi Prastowo, Memahami Metode - Metode Penelitian (Yogyakarta: Ar Ruzz Media, 2016).
} 


\section{Pustakaloka: Zurnal Kajian 2nformasi dan Perpustakaan}

Volume 12 No. 2, Desember 2020

\section{KAJIAN TEORI}

\section{Pengertian Pemustaka}

Di dalam undang-undang Nomor 43 Tahun 2007 tentang Perpustakaan, istilah pengguna atau pemakai Perpustakaan disebut dengan istilah pemustaka, dimana istilah tersebut didefinisikan sebagai perseorangan, kelompok orang, masyarakat atau lembaga yang memanfaatkan fasilitas layanan perpustakaan. Suwarno menyebut pengguna perpustakaan atau pemustaka dengan istilah user, yaitu pengguna fasilitas yang disediakan perpustakaan baik berupa koleksi buku, koleksi bahan pustaka maupun fasilitas lainnya. ${ }^{6}$

Sutarno dalam Suhaila dan Yeni membedakan definisi antara pemakai perpustakaan dengan pengguna perpustakaan, pemakai perpustakaan diartikan sebagai kelompok orang dalam masyarakat yang secara intensif mengunjungi dan memakai layanan dan fasilitas perpustakaan, sedangkan pengguna perpustakaan adalah pengunjung, anggota dan pemakai perpustakaan. ${ }^{7}$

Pemustaka merupakan sasaran utama penyelenggaraan perpustakaan, kehadiran masyarakat (pengguna perpustakaan/pemustaka) menjadi salah satu kunci keberhasilan perpustakaan. ${ }^{8}$ Semegah apapun gedung perpustakaan, atau selengkap apapun koleksi buku perpustakaan, tidak akan dapat dianggap sebagai perpustakaan yang berguna jika tidak ada pemustaka yang dapat memanfaatkan fasilitas tersebut.

Sebagai instansi atau lembaga yang bergerak dalam bidang jasa pelayanan, membangun hubungan yang baik dengan pemustaka merupakan hal yang mutlak untuk dilakukan. Sebuah instansi perpustakaan harus menerapkan paradigma berpikir bagaimana sebuah koleksi yang dimiliki oleh perpustakaan dapat dimanfaatkan dengan baik oleh pemustaka, bukan hanya berorientasi bagaimana caranya memperbanyak atau memperlengkap koleksi yang dimilikinya. Dengan redaksi lain, dapat disebutkan bahwa harus terjadi perubahan

\footnotetext{
${ }^{6}$ Wiji Suwarno, Psikologi Perpustakaan. (Jakarta: Sagung Seto, 2009).

${ }^{7}$ Suhaila Suhaila and Yeni Budi Rachman, "Perilaku Pemustaka Dalam Memperlakukan Koleksi Perpustakaan: Studi Kasus Di Perpustakaan Universitas Indonesia," Jurnal Ilmu Informasi, Perpustakaan, Dan Kearsipan 19, no. 2 (December 19, 2018), https://doi.org/10.7454/jipk.v19i2.125.

${ }^{8}$ Suwarno, Psikologi Perpustakaan., 111.
} 


\section{Radiya Wira Buwana, Mengenal Faktor - Faktor Psikologis Yang ...}

paradigma dari konsep yang diterapkan oleh perpustakaan, yaitu konsep yang menempatkan pemustaka sebagai center dari semua kegiatan yang dilakukan oleh Perpustakaan. ${ }^{9}$ Pemustaka memang layak untuk menjadi sebuah prioritas yang harus diperhatikan oleh para pengelola perpustakaan, karena kunci utama suatu usaha industri jasa pelayanan terletak pada cara perusahaan (dalam konteks ini adalah instansi perpustakaan) tersebut dalam memperlakukan pelangganya. ${ }^{10}$

Dalam memanfaatkan layanan di perpustakaan, menurut Cahyono sebagaimana dikutip oleh Suhaila dan Rachman setidaknya terdapat tiga kebutuhan mendasar dari pengguna perpustakaan yang diharapakan dapat terpenuhi, yaitu : ${ }^{11}$

1. Need for Information, merupakan suatu kebutuhan informasi yang bersifat umum.

2. Need for material and facilities, merupakan kebutuhan untuk mendapatkan koleksi, serta kebutuhan akan fasilitas yang dimiliki Perpustakaan.

3. Need for guidance and support, merupakan kebutuhan untuk mendapatkan petunjuk ataupun bimbingan yang dapat memudahkan/membantu pengguna.

Berperan sebagai konsumen dari bentuk produk jasa yang dilayankan oleh perpustakaan, sangat wajar jika pemustaka selalu memiliki harapan ideal terhadap pelayanan perpustakaan yang prima. Zeithal dan Bitner dalam Herlan dan Budhiono menyebutkan beberapa faktor yang dapat mempengaruhi harapan seorang konsumen akan sebuah bentuk pelayanan yang prima yaitu $:^{12}$

1. Personal Needs, hal dasar yang berpengaruh kepada pemenuhan akan keinginan dan kebutuhan seseorang dalam suatu hal.

2. Explicit service promises, merupakan bentukan komunikasi akan suatu produk pelayanan dari pemberi pelayanan dalam bentuk publikasi tertulis.

\footnotetext{
${ }^{9}$ RM Endar Priyo Utomo, "Peningkatan Kualitas Layanan Berbasis Pemustaka : Sebuah Paradigma Baru Pengukuran Kinerja Perpustakaan," LIBRARIA: Jurnal Perpustakaan 6, no. 1 (June 2018): 140.

${ }^{10}$ Endar Sugiarto, Psikologi pelayanan dalam industri jasa (Jakarta: Gramedia Pustaka Utama, 1999), 196.

${ }^{11}$ Suhaila and Rachman, "Perilaku Pemustaka Dalam Memperlakukan Koleksi Perpustakaan."

12 Herlan Suherlan and Yono Budiono, Psikologi Pelayanan Di Bidang Pariwisata Dan Hospitality Serta Di Berbagai Bidang Bisnis Lainya (Bandung: Media Perubahan, 2013).
} 
3. Implicit service Promises, merupakan indikasi dari janji kualitas produk yang biasanya didasari atas harga dan tampilan fisik dari suatu produk.

4. Word Of Mouth Communication, merupakan komunikasi non formal atau komunikasi dari mulut ke mulut yang didengar oleh konsumen melalui pihak lain akan suatu produk tertentu.

5. Post experience, merupakan komunikasi non formal atau komunikasi dari mulut ke mulut yang didengar oleh konsumen melalui pihak lain akan suatu produk sejenis.

\section{Pengertian Perilaku Pemustaka.}

Perilaku secara umum dapat diartikan sebagai tanggapan atau reaksi individu terhadap rangsangan atau lingkungan. ${ }^{13}$ Dalam konteks perpustakaan, perilaku pemustaka dapat diartikan sebagai bentuk reaksi individu (pemustaka) saat menggunakan jasa perpustakaan, baik itu saat menerima layanan dari pustakawan, saat memanfaatkan koleksi bahan pustaka di perpustakaan atau saat memanfaatkan fasilitas sarana dan prasarana di perpustakaan.

Beberapa bentuk perilaku pemustaka yang sering penulis temukan di perpustakaan antara lain :

1. Pemustaka yang mau mengucapkan terima kasih kepada pustakawan karena buku/bahan pustaka yang mereka butuhkan sudah dapat terpenuhi di perpustakaan.

2. Pemustaka yang ramah dan mau berinteraksi secara positif dengan pustakawan di perpustakaan

3. Pemustaka yang senantiasa "memberondong" pustakawan dengan pertanyaan dan keinginan yang cukup banyak, sehingga pustakawan merasa agak kesulitan untuk memenuhi satu persatu keinginan pemustaka tersebut.

4. Pemustaka yang merasa sok pintar dan suka mendebat, sehingga sulit untuk diberi arahan oleh pustakawan.

5. Pemustaka yang marah saat menyampaikan suatu keluhan kepada pustakawan.

${ }^{13}$ Suherlan and Budiono. 
Radiya Wira Buwana, Mengenal Faktor - Faktor Psikologis Yang ...

6. Pemustaka yang pendiam/tertutup, sehingga tidak terlalu peduli dengan lingkungan perpustakaan di sekitarnya.

7. Pemustaka yang suka mencari sensasi/perhatian di dalam perpustakaan, misalnya dengan berdandan yang berlebihan.

8. Pemustaka yang merasa gugup atau malu untuk bertanya kepada pustakawan, padahal dia merasa memerlukan bantuan.

9. Pemustaka yang kesulitan menerima/memahami arahan dari pustakawan, padahal sudah dijelaskan dengan panjang lebar oleh pustakawan.

10. Pemustaka yang gaptek, dimana sering kita temui beberapa bagian dari masyarakat pengguna perpustakaan yang masih kesulitan untuk mengoperasikan piranti komputer dan browsing internet.

11. Pemustaka yang suka mengganggu pengguna perpustakaan lainnya, misalnya gaduh, berbicara keras-keras di dalam perpustakaan bahkan tertidur di kursi ruang baca koleksi.

12. Pemustaka yang tidak mau mematuhi tata tertib perpustakaan, misalnya membawa makanan dan minuman di perpustakaan.

13. Pemustaka yang berbuat vandalisme atau memiliki sifat merusak, seperti mencorat-coret, merobek/merusak buku, melakukan coart-coret di meja atau kursi perpustakaan.

14. Pemustaka yang secara fisik membutuhkan pelayanan khusus dari pustakawan, misalnya pemustaka yang difabel atau pemustakayang sudah berusia lanjut.

Dari contoh tersebut di atas bisa dilihat bahwa banyak sekali perilaku pemustaka yang dapat terjadi dalam interaksi antara pustakawan dengan pemustaka pada kegiatan pelayanan perpustakaan. Proses interaksi tersebut tentunya dapat berjalan dengan normal, namun terkadang berjalan dengan tidak sebagaimana mestinya sehingga rentan menimbulkan masalah yang menganggu berjalannya kegiatan pelayanan di perpustakaan. Oleh karena itu, seorang pustakawan diharapkan mampu mengakomodasi berbagai bentuk perilaku pemustaka sebelum memutuskan untuk menyelesaikan masalah yang ditemui tersebut. Hal tersebut bisa dikatakan dengan bahasa sederhana bahwa beda jenis 
perilaku yang menimbulkan suatu masalah beda cara penanganannya. Satu hal utama yang harus menjadi perhatian adalah dalam menyelesaikan permasalahan tersebut seorang pustakawan harus mampu mengedepankan pendekatan sisi psikologis dalam menghadapi perilaku pemustaka yang beraneka ragam. Pustakawan tidak dianjurkan untuk menyelesaikan masalah yang menggunakan pendekatan persuasif, baik secara verbal maupun non verbal.

Sebagai lembaga yang bergerak dalam bidang jasa pelayanan, secara ideal tidak boleh satupun kita temui seorang pemustaka yang merasa kecewa atau kapok untuk memanfaatkan kembali jasa pelayanan di perpustakaan sehingga menurunkan minat mereka untuk melakukan kunjungan ulang ke perpustakaan. Pada tingkat yang lebih berbahaya, pemustaka yang mengalami kekecewaan tersebut membagikan rasa kecewa mereka kepada khalayak/ masyarakat luas secara word of mouth atau menuliskanya di media sosial sehingga dapat menimbulkan reaksi negatif dari masyarakat terhadap perpustakaan.

\section{HASIL PENELITIAN DAN PEMBAHASAN}

\section{Faktor-Faktor Psikologis yang Membentuk Perilaku Pemustaka.}

Seorang pustakawan harus meyakini bahwa setiap individu memiliki ciri khas sendiri-sendiri dalam merespon bentuk rangsang (layanan) yang telah diberikan oleh pustakawan sehingga membentuk berbagai perilaku yang telah disebutkan dalam pembahasan sebelumnya. Dalam usaha melakukan pendekatan secara psikologis kepada pemustaka, setelah seorang pustakawan mampu mencatat, menginventarisir dan mengenal beberapa perilaku pemustaka dalam menerima pelayanan di perpustakaan, seorang pustakawan diharapkan mampu mengenal faktor-faktor psikologis apa saja yang dapat berperan membentuk perilaku-perilaku tersebut. Beberapa faktor psikologis yang dapat membentuk perilaku individu pemustaka diantaranya adalah :

1. Inteligensi

Istilah inteligensi berasal dari bahasa latin inteligere yang berarti mengorganisasikan, menghubungkan, atau menyatukan satu dengan yang 


\section{Radiya Wira Buwana, Mengenal Faktor - Faktor Psikologis Yang ...}

lain. ${ }^{14}$ Secara leksikal, intelegensi dapat didefinisikan sebagai daya reaksi atau penyesuaian yang cepat dan tepat, baik secara fisik maupun mental, terhadap pengalaman baru, membuat pengalaman dan pengetahuan yang telah dimiliki siap untuk dipakai apabila dihadapkan pada fakta atau kondisi baru; kecerdasan. ${ }^{15}$ Stern dalam Sujanto menyebutkan bahwa inteligensi adalah kesanggupan jiwa untuk dapat menyesuaikan diri dengan cepat dan tepat dalam situasi yang baru ${ }^{16}$. Dalam redaksi lain disebutkan bahwa intilegensi adalah suatu kemampuan seseorang untuk menangkap rangsangan lingkungan dan mengolah serta menyimpanya dalam diri.

Witherington dalam Khairani mengemukakan bahwa terdapat enam bentuk dari manifestasi inteligensi, yaitu $:^{17}$

a. Kelancaran dan kemudahan dalam penggunaan bilangan.

b. Efisiensi dalam bahasa, dapat dilihat dari pembedaharaan kata-kata, pembedaan lawan kata, kemampuan dalam melengkapi kalimat, membentuk analogi-analogi.

c. Kecepatan dalam pengamatan, kecepatan untuk mengerti, mengetahui secara mendalam atau menyadari suatu obyek, situasi atau suatu hubungan.

d. Kemampuan dalam mengingat.

e. Kemampuan dalam pengertian hubungan-hubungan

f. Khayal, yaitu berupa bentuk khayal yang berguna dalam pendidikan, seperti pengamatan ruang, orientasi temporal dan khayal yang konstruktif.

Dalam konteks layanan perpustakaan, faktor inteligensi seorang pemustaka mempengaruhi tingkat kecerdasan mereka dalam merespon apa yang telah disampaikan oleh perpustakaan atau pustakawan. Seorang pustakawan dapat menggunakan bahasa-bahasa yang sederhana dalam berinteraksi dengan pemustaka, bahasa yang sekiranya mampu ditangkap oleh seluruh lapisan masyarakat pengguna perpustakaan. Tingkat inteligensi yang

\footnotetext{
${ }^{14}$ Bimo Walgito, Pengantar Psikologi Umum (Yogyakarta: Andi, 2009), 143.

15“Hasil Pencarian - KBBI Daring," accessed August 11, 2020, https://kbbi.kemdikbud.go.id/entri/inteligensi.

${ }^{16}$ Agus Sujanto, Psikologi Umum (Jakarta: Bumi Aksara, 2004), 66.

${ }^{17}$ Makmun Khairani, Psikologi Umum (Yogyakarta: Aswaja Pressindo, 2016).
} 
berbeda-beda pada setiap pribadi pemustaka hendaknya perlu dicermati oleh pustakawan saat melaksanakan kegiatan pelayanan. Secara sederhana, misalnya dapat dilihat bagaimana kemampuan pemustaka untuk dapat menemukan suatu lokasi ruangan koleksi dengan melihat papan informasi lokasi yang sudah disediakan di perpustakaan tanpa harus bertanya. Contoh yang lain misalnya, kemampuan pemustaka untuk mencerna uraian yang telah disampaikan oleh pustakawan mengenai sumber bahan pustaka yang sedang mereka konsultasikan kepada pustakawan, kemampuan berbahasa seorang pengguna perpustakaan untuk meminta bantuan kepada pustakawan dan kemampuan pemustaka untuk berdiskusi dengan pustakawan dengan pemilihan bahasa yang santun/sopan.

2. Persepsi

Secara umum persepsi dapat diartikan sebagai proses seseorang mengetahui beberapa hal melalui panca indranya atau diartikan sebagai tanggapan (penerimaan) langsung dari sesuatu. ${ }^{18}$ Persepsi dapat diartikan sebagai suatu proses dengan cara apa seseorang melakukan pemilihan, penerimaan, pengorganisasian, dan penginterprestasian atas informasi yang diterima di lingkunganya. ${ }^{19}$ Dalam redaksi yang lain, disebutkan bahwa persepsi adalah suatu proses membuat penilaian atau membangun kesan mengenai berbagai macam hal yang terdapat di dalam lapangan penginderaan seseorang. ${ }^{20}$

Dalam menerima pelayanan di perpustakaan, seorang pemustaka akan memiliki persepsi yang berbeda terhadap bentuk pelayanan yang diberikan oleh pustakawan. Persepsi merupakan proses informasi dalam diri kita untuk mengenali atau membuat kita mengetahui dan mengerti hal-hal yang kita hadapi ${ }^{21}$. Seseorang dapat saja melakukan persepsi yang keliru dalam memahami sesuatu hal sehingga terkadang menjadi bermasalah dalam proses

\footnotetext{
18“"Hasil Pencarian - KBBI Daring," accessed August 11, 2020, https://kbbi.kemdikbud.go.id/entri/persepsi.

${ }^{19}$ Herlan Suherlan and Yono Budhiono, Psikologi Pelayanan: Di Bidang Pariwiasata Dan Hospitality Serta Di Berbagai Bidang Bisnis Lainnya (Bandung: Media Perubahan, 2013), 21.

${ }^{20}$ Wiji Suwarno, Psikologi Perpustakaan (Jakarta: Sagung Seto, 2009), 52.

${ }^{21}$ Suwarno, 58.
} 


\section{Radiya Wira Buwana, Mengenal Faktor - Faktor Psikologis Yang ...}

interaksi. Misalnya, seorang pustakawan yang melayani pengguna dengan terburu-buru seringkali dipersepsikan sebagai pustakawan yang tidak ramah terhadap pengguna, padahal sebenarnya pustakawan tersebut sedang dibebani target untuk menyelesaikan laporan bulanan. Atau dalam contoh yang lain seorang pemustaka yang mempersepsikan sikap ramah pustakawan sebagai tanda ketertarikan, atau beberapa pemustaka ada yang merasa kurang nyaman dengan sikap "terlalu ramah" dari pustakawan.

Kejadian-kejadian tersebut di atas dapat digolongkan sebagai sebuah peristiwa yang bernama distorsi dalam persepsi. Beberapa distorsi dalam persepsi antara lain adalah :

a. Stereotip yaitu kecenderungan untuk menggenerralisasikan atribut dari kelompok pada anggota kelompoknya secara pribadi. Beberapa contoh stereotif yang kita kenal antara lain: stereotif ras, stereotif gender dan stereotif umur.

b. Efek halo, yaitu kecenderungan untuk menggunakan hanya satu ciri saja dalam mengevaluasi keseluruhan individu.

c. Seleksi, yaitu kecenderungan untuk hanya memperhatikan aspek-aspek tertentu dari seseorang dari suatu situasi yang sesuai dengan kepercayaan, nilai dan kebutuhan kita.

d. Proyeksi, yaitu menempatkan atribut diri pribadi kita pada orang lain. Atau memproyeksikan sesuatu yang ada dalam diri kita, pada orang lain.

e. Harapan, yaitu membuat langkah antisipasi akan suatu kejadian, dan kemudian menciptakan situasi yang membuat harapan tersebut menjadi kenyataan. 22

Untuk mengurangi beberapa masalah yang diakibatkan oleh "tangkapan beda persepsi” dari pemustaka, pustakawan sebaiknya mampu mengaplikasi beberapa langkah berikut ini :

a. Mempertinggi tingkat mawas diri, maksudnya adalah berhati-hati agar tidak terjadi salah persepsi.

${ }^{22}$ Suherlan and Budhiono, Psikologi Pelayanan: Di Bidang Pariwiasata Dan Hospitality Serta Di Berbagai Bidang Bisnis Lainnya, 24-25. 


\section{Pustakaloka: Zurnal Kajian 2nformasi dan Perpustakaan}

Volume 12 No. 2, Desember 2020

b. Mengupayakan kelengkapan informasi, maksudnya adalah jangan separuhseparuh dalam menyampaikan informasi kepada pengguna Perpustakaan.

c. Empati, yaitu mencoba merasakan bagaimana jika kita berada pada posisi sebagai pemustaka.

d. Menghindari segala macam distorsi yang mungkin terjadi dalam proses persepsi, baik yang dilakukan dalam diri sendiri ataupun orang lain ${ }^{23}$.

3. Kepribadian

Faktor kepribadian memegang peranan yang menentukan mengapa di dalam perpustakaan terdapat pemustaka dengan tipe-tipe yang bernaneka ragam. Beberapa tipe pemustaka yang sering kita temui antara lain, pemustaka yang pendiam, pemustaka yang ramah, pemustaka yang banyak bertanya, pemustaka yang over acting, pengguna perpustakaan yang suka mencari sensasi, dan lain sebagainya.

Secara istilah, kepribadian dapat diartikan sebagai sifat hakiki yang tercermin pada sikap seseorang yang membedakannya dari orang lain ${ }^{24}$. Allport dalam Suherlan dan Budhiono mendefiniskan bahwa kepribadian adalah suatu organisasi psikofisik yang dinamis dalam diri individu, yang menetukan tingkah laku yang khas (unik) dari orang tersebut. Sementara dalam redaksi lain, Adler dalam Suherlan dan Budhiono mendefinisikan bahwa kepribadian adalah gaya hidup individu, atau cara yang khas dari individu tersebut dalam merespon masalah-masalah hidup. ${ }^{25}$

Dari beberapa definisi tersebut di atas, dapat ditarik benang merah bahwa kepribadian selalu menggambarkan keadaan keunikan seseorang. Seorang pustakawan diharapkan dapat menganalisis kepribadian seseorang pemustaka untuk dapat menyesuaikan diri dalam menghadapi situasi pelayanan. Untuk dapat menganalisis kepribadian seorang pemustaka, pustakawan dapat melihat gambaran karakteristik seorang pemustaka.

\footnotetext{
${ }^{23}$ Suherlan and Budhiono, 26.

24“"Hasil Pencarian - KBBI Daring," accessed August 11, 2020, https://kbbi.kemdikbud.go.id/entri/kepribadian.

${ }^{25}$ Suherlan and Budiono, Psikologi Pelayanan Di Bidang Pariwisata Dan Hospitality Serta Di Berbagai Bidang Bisnis Lainya.
} 
Radiya Wira Buwana, Mengenal Faktor - Faktor Psikologis Yang ...

Khairani menyebutkan beberapa karakteristik yang dianggap penting untuk mengenali kepribadian seseorang adalah $:^{26}$

a. Penampilan fisik, penampilan fisik dan cara berpakaian menunjukan apakah seseorang berwibawa dan percaya pada diri sendiri atau kurang semangat dan mempunyai perasaan rendah diri.

b. Tempramen, yaitu suasana hati yang menetap dan khas pada orang yang bersangkutan. Misalnya pemurung, pemarah, periang dan sebagainya

c. Kecerdasan dan kemampuan aktuilnya

d. Arah dan minat serta pandangan mengenai nilai-nilai.

e. Sikap sosial.

f. Kecenderungan-kecenderungan dalam motivasinya.

g. Cara-cara pembawaan diri, misalnya sopan santun, banyak bicara, kritis, mudah bergaul, dll.

h. Kecenderungan patologis, yaitu tanda-tanda adanya kelainan kepribadian seperti rekasi-reaksi psikopatik, psikosis, neurosis, phobia,skizoitenis, dan lain sebagainya.

4. Sikap

Sikap dapat diartikan sebagai perilaku; gerak-gerik atau bisa diartikan sebagai perbuatan dan sebagainya yang berdasarkan pada pendirian, keyakinan ${ }^{27}$. Dalam uraian yang lain, sikap dapat didefiniskan sebagai suatu kecenderungan individu untuk berperilaku berdasarkan penilaian individu terhadap suatu obyek yang berentang dari positif, netral hingga negatif ${ }^{28}$. Sikap seorang dapat diamati dari perilaku yang dilakukan oleh seseorang. Sikap seseorang sebagian besar dipengaruhi oleh pengalaman seseorang serta reaksi emosi yang menyertai pengalamanya. ${ }^{29}$

Perilaku pemustaka terkadang dipengaruhi oleh sikap mereka berdasarkan pengalaman yang sudah pernah mereka alami di perpustakaan.

${ }^{26}$ Khairani, Psikologi Umum, 2016.

27"Hasil Pencarian - KBBI Daring," accessed August 11, 2020, https://kbbi.kemdikbud.go.id/entri/sikap.

${ }^{28}$ Suherlan and Budhiono, Psikologi Pelayanan: Di Bidang Pariwiasata Dan Hospitality Serta Di Berbagai Bidang Bisnis Lainnya, 41.

${ }^{29}$ Suherlan and Budhiono, 41. 


\section{Pustakaloka: Zurnal Kajian 2nformasi dan Perpustakaan}

Volume 12 No. 2, Desember 2020

Seorang pemustaka yang pernah mendapatkan pelayanan yang tidak ramah dari pustakawan cenderung akan menimbulkan rasa kecewa bahkan marah yang pada akhirnya dapat mengurungkan niat untuk datang ke perpustakaan lagi. Namun sebaliknya, jika seorang pemustaka merasa sangat terbantu dan terlayani dengan baik oleh pustakawan maka akan meningkatkankeinginan mereka untuk kembali memanfaatkan jasa layanan di Perpustakaan bahkan dapat menjadikan sebuah promosi dari mulut ke mulut (word of mouth) kepada masyarakat luas tentang kualitas pelayanan di perpustakaan tersebut. Secara umum, dapat disebutkan bahwa sikap pengguna jasa pelayanan dapat terbentuk oleh 4 hal, yaitu hasil belajar, pengalaman, kepercayaan, dan cerita dari orang lain ${ }^{30}$.

5. Motivasi

Motivasi dapat diartikan sebagai usaha yang dapat menyebabkan seseorang atau kelompok orang tertentu tergerak melakukan sesuatu karena ingin mencapai tujuan yang dikehendakinya atau mendapat kepuasan dengan perbuatannya $^{31}$. Dalam uraian lain, motivasi didefinisikan sebagai energi aktif yang menyebabkan terjadinya suatu perubahan pada diri seseorang yang nampak pada gejala kejiwaan, perasaan, dan juga emosi, sehingga mendorong individu untuk bertindak atau melakukan sesuatu dikarenakan adanya tujuan, kebutuhan atau keinginan yang terpuaskan ${ }^{32}$.

Setiap pemustaka dipastikan memiliki motivasi yang berbeda untuk berkunjung ke perpustakaan. Beberapa pemustaka (biasanya pelajar, mahasiswa atau peneliti) datang ke perpustakaan dengan motivasi untuk mencari bahan pustaka yang mereka butuhkan untuk keperluan studi. Beberapa pemustaka ada yang datang ke perpustakaan untuk refreshing, sekedar nongkrong atau bersosialisasi dengan sesama rekan. Dari dua saja contoh bentuk motivasi pemustaka tersebut, tentunya akan melahirkan perilaku yang berbeda dalam memanfaatkan layanan di perpustakaan. Untuk

\footnotetext{
${ }^{30}$ Suherlan and Budhiono, 57.

31"Hasil Pencarian - KBBI Daring," accessed August 12, 2020, https://kbbi.kemdikbud.go.id/entri/motivasi.

${ }^{32}$ Makmun Khairani, Psikologi Umum (Yogyakarta: Aswaja Pressindo, 2016), 131.
} 


\section{Radiya Wira Buwana, Mengenal Faktor - Faktor Psikologis Yang ...}

motivasi akademis (studi), pemustaka akan cenderung berperilaku lebih tenang dan serius di perpustakaan, sedangkan untuk motivasi refreshing atau bersosialisasi maka akan cenderung menimbulkan perilaku pemustaka yang santai, easy going, have fun, serta cenderung menimbulkan kegaduhan di dalam perpustakaan.

Khairani menyebutkan bahwa motivasi seseorang sangat dipengaruhi oleh dua faktor, yaitu : ${ }^{33}$

a. Faktor internal, yaitu faktor yang berasal dari dalam diri individu, terdiri atas :

1) Persepsi individu mengenai diri sendiri.

2) Harga diri dan prestasi.

3) Harapan.

4) Kebutuhan.

5) Kepuasan.

b. Faktor eksternal, yaitu faktor yang berasal dari luar individu, terdiri atas :

1) Jenis dan sifat pekerjaan.

2) Kelompok/organisasi dimana individu tersebut bergabung.

3) Situasi lingkungan pada umumnya.

4) Sistem imbalan yang diterima.

\section{PENUTUP}

Interaksi antara pustakawan dengan pemustaka dalam kegiatan pelayanan di perpustakaaan memegang peranan penting pada terciptanya layanan yang prima di perpustakaan. Keanekaragaman masyarakat pengguna perpustakaan (pemustaka) dari berbagai hal seperti tingkat pendidikan, tingkat kemampuan ekonomi, kelas sosial, maupun kultur budaya, menciptakan keanekaragaman perilaku pemustaka dalam memanfaatkan jasa layanan di perpustakaan.

Untuk dapat mewujudkan pelayanan prima di sebuah perpustakaan, salah satu hal yang dapat dilakukan oleh seorang pustakawan adalah harus mampu

${ }^{33}$ Khairani, Psikologi Umum, 2016. 
untuk memahami perilaku para pemustaka. Dalam memahami perilaku-perilaku pemustaka, seorang pustakawan dapat melakukannya melalui pendekatan psikologis kepada pemustaka. Menggunakan sudut pandang kajian ilmu psikologi, pendekatan psikologis yang dilakukan oleh pustakawan dapat memperhatikan beberapa faktor psikologis yang dapat membentuk perilaku pemustaka. Faktorfaktor psikologis tersebut antara lain adalah, inteligensi, persepsi, kepribadian, sikap dan motivasi.

\section{DAFTAR RUJUKAN}

Badan Pengembangan dan Pembinaan Bahasa, Kementerian Pendidikan dan Kebudayaan Republik Indonesia. Kamus Besar Bahasa Indonesia Versi Daring, https://kbbi.kemdikbud.go.id

Iskandar, Iskandar. Manajemen Dan Budaya Perpustakaan. Bandung: Refika Aditama, 2016.

Khairani, Makmun. Psikologi Umum. Yogyakarta: Aswaja Pressindo, 2016.

—. Psikologi Umum. Yogyakarta: Aswaja Pressindo, 2016.

Prastowo, Andi. Manajemen Perpustakaan Sekolah Profesional. Yogyakarta: Diva Press, 2013.

— Memahami Metode - Metode Penelitian. Yogyakarta: Ar Ruzz Media, 2016.

Rahayu, Lisda, and dkk. Layanan Perpustakaan. Jakarta: Universitas Terbuka, 2019.

Sugiarto, Endar. Psikologi pelayanan dalam industri jasa. Jakarta: Gramedia Pustaka Utama, 1999.

Suhaila, Suhaila, and Yeni Budi Rachman. "Perilaku Pemustaka Dalam Memperlakukan Koleksi Perpustakaan: Studi Kasus Di Perpustakaan Universitas Indonesia." Jurnal Ilmu Informasi, Perpustakaan, Dan Kearsipan 19, no. 2 (December 19, 2018). https://doi.org/10.7454/jipk.v19i2.125.

Suherlan, Herlan, and Yono Budhiono. Psikologi Pelayanan: Di Bidang Pariwiasata Dan Hospitality Serta Di Berbagai Bidang Bisnis Lainnya. Bandung: Media Perubahan, 2013.

Sujanto, Agus. Psikologi Umum. Jakarta: Bumi Aksara, 2004.

Suwarno, Wiji. Psikologi Perpustakaan. Jakarta: Sagung Seto, 2009.

Utomo, RM Endar Priyo. "Peningkatan Kualitas Layanan Berbasis Pemustaka: Sebuah Paradigma Baru Pengukuran Kinerja Perpustakaan.” LIBRARIA: Jurnal Perpustakaan 6, no. 1 (June 2018).

Walgito, Bimo. Pengantar Psikologi Umum. Yogyakarta: Andi, 2009. 